\title{
The influence of sex steroid hormones on ferrochelatase gene expression in Harderian gland of hamster (Mesocricetus auratus)
}

\author{
F Vilchis, L Ramos, C Timossi and B Chávez \\ Department of Reproductive Biology, Instituto Nacional de Ciencias Médicas y Nutrición Salvador Zubirán, Vasco de Quiroga no. 15, Del. Tlalpan C.P. 14000, \\ México D.F., Mexico \\ (Requests for offprints should be addressed to B Chávez; Email: bachavez@prodigy.net.mx)
}

\begin{abstract}
Ferrochelatase (protohaem ferrolyase, EC 4.99.1·1), the terminal enzyme of the haem biosynthetic pathway, catalyses the insertion of ferrous iron into protoporphyrin IX to form protohaem. The Syrian hamster Harderian gland (HG) is known for its ability to produce and accumulate large amounts of protoporphyrins. In this species, the female gland contains up to 120 times more porphyrin than the male gland. Data from biochemical studies suggest that this gland possesses the enzymatic complex for haem biosynthesis but lacks ferrochelatase activity. The abundance of intraglandular haem proteins does not support this idea. To gain more insight into this process, we isolated cDNA for ferrochelatase from hamster liver, using the $5^{\prime}$ - and $3^{\prime}$ - rapid amplification of complementary DNA ends (RACE), and investigated its expression in HG from males and females. The full-length cDNA comprises an open reading frame of $1269 \mathrm{bp}$ encoding a polypeptide of 422 amino-acid residues. Hamster DNA sequence exhibits 92\% identity to mouse and $87 \%$ identity to human sequences. The predicted hamster enzyme was shown to have structural features of mammalian ferrochelatase, including a putative $\mathrm{NH}_{2}-$ terminal presequence, a central core of about 330 amino-acid
\end{abstract}

residues and an extra 30-50-amino-acid stretch at the carboxyl-terminus. RNA blotting experiments indicated that this cDNA hybridized to a liver mRNA of about $2 \cdot 1 \mathrm{~kb}$, while a weak hybridization signal was observed with mRNA from HG preparations. RT-PCR assays confirmed the expression of specific transcripts in both tissues. Male glands contained approximately twofold more enzyme mRNA than female glands. Likewise, the intraglandular content of mRNA varied during the oestrous cycle, with the highest levels found in the oestrous phase. These cyclic variations were less evident in liver. Ovariectomy plus treatment with progesterone or $17 \beta$-oestradiol plus progesterone increased ferrochelatase mRNA of the gland. In HG of short- or long-term castrated males, the administration of testosterone did not affect the ferrochelatase mRNA concentration. Based on mRNA expression levels, we conclude that Harderian ferrochelatase may play an active role in maintaining the physiological pool of haem required for processing cytochromes and other glandular haem proteins. Likewise, the sex-steroid hormones appear to have only a modest influence upon Harderian ferrochelatase.

Journal of Endocrinology (2006) 189, 103-112

\section{Introduction}

The Harderian gland (HG) is a compound tubuloalveolar structure located within the orbital cavities of most terrestrial vertebrates. Its function remains unclear, although it has been linked to a retino-pineal-gonadal system (Wetterberg et al. 1970) and may serve as a potential source of pheromones (Payne 1994) and as a secondary steroidogenic organ (Vilchis et al. 2002). Characteristically in Syrian hamster, the HG produces and accumulates large amounts of porphyrins, which can be microscopically visualized as solid intraluminal accretions (Christensen \& Dam 1953, Hoffman 1971, Payne et al. 1977). The HG appears to express the whole enzymatic complex required for porphyrin synthesis from glycine and succinyl-CoA (Tomio \& Grinstein 1968).
Interestingly, some steps of the biosynthetic pathway, including protoporphyrin IX production, are under hormonal influence. In this regard, Thompson et al. (1984) reported marked sex differences in five of the seven haem biosynthetic enzymes, with higher activities always being found in females. Porphobilinogen deaminase, uroporphyrinogen decarboxylase, coproporphyrinogen oxidase and protoporphyrinogen oxidase are among the enzymes whose activity is influenced by sex steroids (Spike et al. 1992, Gibson et al. 1999, Coto-Montes et al. 2001). In fact, the female hamster has considerably more porphyrins than the male (Spike et al. 1985, 1986). These sexual differences may be easily reversed by changes in sex hormones; castration of adult males increases the intraglandular content of these pigments, and administration of androgens to adult females decreases their intraglandular content 
(Hoffman 1971, McMasters \& Hoffman 1984). In addition, the porphyrinogenic activity of the gland fluctuates throughout the oestrous cycle, pregnancy and lactation, suggesting that there is a link between HG activity and reproductive function (Moore et al. 1977, Payne et al. 1979). Previous reports have indicated that, apart from the gonadal steroids, other hormones from the pituitary (Buzzell et al. 1992), the thyroid (Hoffman et al. 1990) and the pineal gland (McMasters \& Hoffman 1984) may regulate porphyrin synthesis in $\mathrm{HG}$.

The rate-limiting step of the haem production is catalysed by 5 -aminolevulinic acid synthase 1 (ALA-S1), an enzyme whose synthesis is under feedback inhibition by haem, and which is also negatively regulated by iron levels and androgens (Veltman \& Maines 1985, Drew \& Ades 1986, Menéndez-Peláez et al. 1991, Domínguez et al. 1994, Taketani et al. 2000). Haem not only serves as a prosthetic group of numerous haem proteins that synthesize important regulatory and signalling molecules, including cyclic GMP, steroid hormones and nitric oxide, but it also plays a key role in controlling protein synthesis and cell differentiation (Ponka 1999). In most tissues, porphyrins are converted to haem by ferrochelatase. However, the expression of this enzyme in HG is still a matter of controversy, especially because of its low or almost undetectable activity (Thompson et al. 1984, Nagai et al. 1997). Nevertheless, the relative abundance of cholesterol side-chain cleavage cytochrome P450scc (Vilchis et al. 2002), together with the large amount of androgen-regulated haem proteins (Vilchis et al. 1996) and the high concentrations of intraglandular iron (Hoffman \& Jones 1981), strongly suggests a functional role for this mitochondrial enzyme. By isolating the specific cDNA, we provide experimental evidence of the transcriptional activity of ferrochelatase in HG.

\section{Materials and Methods}

\section{Animals and tissues}

Male and female adult hamsters (Mesocricetus auratus) weighing 130-180 g were housed under controlled conditions (temperature $21 \pm 2{ }^{\circ} \mathrm{C}$; lighting, $14 \mathrm{~h}: 10 \mathrm{~h} /$ light:darkness) with free access to food and water. The hamsters were orchidectomized under light ether anaesthesia and were allowed 7 days to recover before study. Other groups of male hamsters were castrated for 7 or 30 days and then injected with a daily dose of testosterone $(1 \mathrm{mg})$ or vehicle alone $(50 \mu \mathrm{l}$ corn oil) for 6 consecutive days. In females, the ovarian cycle was monitored with vaginal smear patterns, considering that ovulation occurs at a mean of every 4 days with proestrus $(\mathrm{P})$, oestrus (E), metoestrus (M) and dioestrus (D) phases. Other groups of females were ovariectomized for 7 days and then treated with a daily dose of $17 \beta$-oestradiol $(10 \mu \mathrm{g})$ or progesterone $(1 \mathrm{mg})$ or $17 \beta$-oestradiol plus progesterone $(10 \mu \mathrm{g}$ plus $1 \mathrm{mg})$ or vehicle alone $(50 \mu \mathrm{l}$ corn oil) for 6 consecutive days. The experimental procedures were approved by the institutional ethical committee for investigation in animals. Animals were decapitated, and tissues were immediately excised, rapidly frozen and stored at $-70{ }^{\circ} \mathrm{C}$ until assayed.

\section{Extraction of RNA}

Total cellular RNA was isolated with TRIzol reagent (Invitrogen). The amount and quality of RNA were estimated by spectrophotometry at 260/280 nm. Once total RNA was isolated, polyadenylated [poly $(\mathrm{A})^{+}$] RNA was obtained with the Fast Track mRNA isolation kit (Invitrogen) by the manufacturer's recommended protocol. Total RNA or poly $(A)^{+}$RNA was reverse transcribed into complementary DNA (cDNA) with the $1^{\text {st }}$ Strand cDNA Synthesis kit for RT-PCR (Roche).

\section{Isolation of hamster ferrochelatase $\mathrm{cDNA}$}

Initially, oligo-dT-primed cDNA from male liver and two sets of degenerate primers designed from the sequences reported for mouse (Taketani et al. 1990, Brenner \& Frasier 1991), human (Nakahashi et al. 1990) and bovine (Shibuya et al. 1995) ferrochelatase were used to amplify specific transcripts of hamster mRNA. The PCR products were resolved on agarose gels, eluted and purified through Centricon-30 columns (Amicon Millipore Co, Bedford, MA, USA), and submitted for sequencing analysis. These partial cDNA sequences were then aligned with that of mouse ferrochelatase and shown to have a highly conserved nucleotide sequence, confirming their authenticity. Gene-specific primers derived from these fragments were used in further procedures to amplify the $5^{\prime}$ - and $3^{\prime}$ - end regions, by the method of rapid amplification of the cDNA ends (RACE).

Starting from male liver poly (A) ${ }^{+}$RNA, $5^{\prime}$-and $3^{\prime}$ RACE reactions were performed with the Gene Racer (RLM-RACE) kit from Invitrogen according to the manufacturer's instructions. The complete cDNA sequence was obtained by PCR using gene-specific primers, designed from the $5^{\prime}-$ and $3^{\prime}$-RACE fragments. The forward and reverse primers used in the reactions were as follows: FPLUS (5'-GATCCCTGGCGTCCCGGAAA TGCTT- $3^{\prime}$ ) and FMIN (5'-TCTGTGAATCCCACGG GTCCTCAG- $\left.3^{\prime}\right)$. After 35 cycles of amplification $\left(94^{\circ} \mathrm{C}\right.$ for $60 \mathrm{~s}, 65^{\circ} \mathrm{C}$ for $45 \mathrm{~s}, 72{ }^{\circ} \mathrm{C}$ for $45 \mathrm{~s}$, with a 7 -min final extension at $\left.72{ }^{\circ} \mathrm{C}\right)$, the PCR products $(1320 \mathrm{bp})$ were ligated into the TA cloning vector pcDNA3-1/V5-HisTOPO (Invitrogen). After the plasmid was amplified by transforming competent cells, it was purified and subjected to restriction analysis with EcoRV and BamH1 to verify orientation of the inserted DNA. At least three positive clones were sequenced in both directions in order to establish the complete cDNA sequence. 
The nucleotide sequences of PCR products and clones were determined with the Thermo Sequenase $\left(\left[\alpha_{-}{ }^{33} \mathrm{P}\right] \mathrm{ddNTP}\right)$ Radiolabeled Terminator Cycle Sequencing kit (USB Co, Cleveland, OH, USA).

\section{Northern blot analysis}

Aliquots of total RNA $(20 \mu \mathrm{g})$ isolated from each tissue sample were electrophoresed on a $1 \cdot 2 \%$ agarose $/ 6 \cdot 0 \%$ formaldehyde gel, transferred to Hybond $\mathrm{N}^{+}$nylon membrane (Amersham) by capillary diffusion and then fixed by UV cross-linking. Filters were prehybridized for $4 \mathrm{~h}$ at $65^{\circ} \mathrm{C}$ in a Rapid-hyb buffer solution (Amersham) and further hybridized overnight at $65^{\circ} \mathrm{C}$ in the same solution.

A $730 \mathrm{bp}$ PCR product, amplified from ferrochelatase cDNA with the internal primers MA7; MA22 (5'-CGT CCATCCTTTGACAGAAGAAGC-3'; 5'-GATTTACAC AGAGCGGGCAGC-3'), was labelled with $\left[\alpha-{ }^{32} \mathrm{P}\right] \mathrm{dCTP}$ by random primer (RadPrime DNA Labeling System; Invitrogen) and used as probe in Northern and Southern blot assays. After hybridization and washing, the blots were exposed to Kodak BioMax XAR films at $-70{ }^{\circ} \mathrm{C}$ for $2-8 \mathrm{~h}$.

\section{RT-PCR/Southern blot analysis}

Oligo-dT-primed cDNA from each RNA was synthesized as described above and subsequently amplified with the primers FPLUS-FMINUS. The expected product size was $1320 \mathrm{bp}$. Parallel incubations containing no AMV-RT enzyme were used as controls in RT-PCR reactions. For Southern blots, $5 \cdot 0 \mu \mathrm{l}$ aliquots of RT-PCR products were separated by electrophoresis on $1 \%$ agarose gel containing ethidium bromide and visualized under UV light. The same gel was transferred to a nylon membrane and hybridized under similar conditions to those described for Northern blot. For the study of ferrochelatase expression levels in males and females, $1 \cdot 0 \mu \mathrm{l}(1 / 20)$ of each RT reaction (from liver and HG) was used to amplify a $730 \mathrm{bp}$ fragment from cDNA with 30 cycles of the following PCR conditions: $94^{\circ} \mathrm{C}$ for $60 \mathrm{~s}$, $58^{\circ} \mathrm{C}$ for $45 \mathrm{~s}, 72{ }^{\circ} \mathrm{C}$ for $45 \mathrm{~s}$ and a final extension step at $72{ }^{\circ} \mathrm{C}$ for $7 \mathrm{~min}$. A control PCR was performed with all cDNAs using primers for the ubiquitous protein cyclophilin [5'-CCCCACCGTGTTCTTCGA-3' (sense) and 5'-AGGTCCTTACCGTTCTGGTCG-3' (antisense)], which yielded a $453 \mathrm{bp}$ fragment. Aliquots of $5 \cdot 0 \mu \mathrm{l}$ from each RT-PCR reaction were analysed on $1 \%$ agarose gel containing ethidium bromide and evaluated by densitometry with the Eagle-Eye II still video system (StrataGene, La Jolla, CA, USA).

\section{Statistical analysis}

Densitometric data were expressed as the mean value \pm S.D. of three independent RT-PCR determinations. For each experimental group, the relative density value from six or seven samples $(n)$ was evaluated. Differences between groups were assessed by Kruskal-Wallis one-way analysis of variance by ranks (Siegel \& Castellan 1988). Significant differences were accepted at $P<0 \cdot 05$.

\section{Results}

\section{cDNA cloning}

To complete the hamster ferrochelatase cDNA sequence, 5'- and 3'-RACE was performed on adapter-ligated liver RNA. PCR products of 995 and 340 bp were obtained for the 5'- and 3'-RACE respectively; both products were sequenced with nested primers. Reverse transcription and PCR amplification of the poly $(A)^{+}$RNA in the presence of gene-specific primers resulted in the amplification of a $1.3 \mathrm{~kb}$ fragment, which was inserted into the cloning vector. Overlay of these cDNA fragments provided the entire nucleotide sequence of hamster ferrochelatase mRNA.

The nucleotide sequence and deduced amino-acid sequence of hamster ferrochelatase cDNA are shown in Fig. 1. The overall sequence of the cDNA isolated in this study contained 2175 nucleotides, consisting of $70 \mathrm{bp}$ of the $5^{\prime}$-untranslated region (UTR), $1269 \mathrm{bp}$ of the open reading frame (ORF) and a long 3'-UTR of $836 \mathrm{bp}$. One canonical polyadenylation motif (AATAAA) is found at position 2085, $14 \mathrm{bp}$ upstream of the poly (A)-trail. The ORF of the hamster ferrochelatase encodes for a protein of 422 amino acids and an estimated molecular weight of 47569 Da. Signal peptide prediction by the SignalP program identifies the first 53-amino-acid residues as a putative $\mathrm{NH}_{2}$ presequence with a cleavage site at residues 26-27. In Fig. 1, the first AUG codon is the initiator codon, although the flanking region around the second methionine conforms to the Kozak consensus (Kozak 1987).

\section{Protein sequence}

A comparison of the amino-acid sequence of hamster ferrochelatase with that of other species shows extensive homologies in certain regions (Fig. 2). Overall identities of amino-acid sequences between hamster and mouse, human, chicken, Xenopus and Danio ferrochelatase are $95 \%, 89 \%, 87 \%, 79 \%$ and $74 \%$ respectively. The predicted protein sequence contains the cysteine residues that contribute to the [2Fe-2S] cluster (Fig. 2), as well as a number of well-conserved amino-acid residues, believed to interact with the porphyrin substrate and with iron substrate binding.

\section{$m R N A$ expression}

Northern blot hybridization of RNA samples from hamster tissues with the ${ }^{32} \mathrm{P}$-labelled probe of ferrochelatase showed that expression of a $2 \cdot 1-\mathrm{kb}$ mRNA was 
-70 gccetggttcggtaggcgctcgctggcettgctgtagcgccgccgcagaggatccetggccgtcccggaa

ATG CTT TCG GCC GGC GCC AAC ATG GCC GCA GCC CTG CGG GCT GCC GGC GCG CTG CTC CGC 60 Met Leu Ser Ala Gly Ala Asn Met Ala Ala Ala Leu Arg Ala Ala Gly Ala Leu Leu Arg 20

CAG CCG CTG GCG CAT GGC AGC TCG AGG GCC TGT CAG CCA TGG AGG TGC CAG TCG GGT GCG 120 Gln Pro Leu Ala His Gly ser ser Arg Ala Cys Gln Pro Trp Arg Cys Gln Ser Gly Ala 40

GCG GCA GCG GCC ACC ACA GAG AAA GTG CAT CAT GCC AAA ACT GCA AAG CCT CAA GCT CAA 180 Ala Ala Ala Ala Thr Thr Glu Lys val His His Ala Lys Thr Ala Lys pro Gln Ala Gln 60

CCA GAA AGG AGG AAG CCA AAA ACC GGC ATA TTA ATG TTA AAC ATG GGG GGC CCC GAA ACC 240 Pro Glu Arg Arg Lys Pro Lys Thr Gly Ile Leu Met Leu Asn Met Gly Gly Pro Glu Thr 80

CTT GGA GAA GTT CAA GAC TTC CTT CAA AGA CTC TTC TTG GAC CGA GAC CTC ATG ACA CTT 300 Leu Gly Glu Val Gln Asp phe Leu Gln Arg Leu phe Leu Asp Arg Asp Leu Met Thr Leu 100

CCC ATT CAA AAC AAG CTG GCA CCA TTC ATC GCC AAA CGC CGA ACC CCC AAA ATT CAA GAG 360 Pro Ile Gln Asn Lys Leu Ala Pro phe Ile Ala Lys Arg Arg Thr Pro Lys Ile Gln Glu 120

CAG TAT CGC AGG ATT GGA GGT GGC TCC CCC ATC AAG ATG TGG ACT TCC AAG CAA GGA GAA 420 Gln Tyr Arg Arg Ile Gly Gly Gly Ser Pro Ile Lys Met Trp Thr ser Lys Gln Gly Glu 140

GGC ATG GTG AAG TTG CTG GAT GAG CTG TCC CCT GAC ACA GCA CCT CAC AAA TAC TAT ATT 480 Gly Met val Lys Leu Leu Asp Glu Leu Ser Pro Asp Thr Ala Pro His Lys Tyr Tyr Ile 160

GGA TTC CGG TAC GTC CAT CCT TTG ACA GAA GAA GCA ATT GAA GAG ATG GAG AGA GAT GGC 540 Gly Phe Arg Tyr Val His pro Leu Thr Glu Glu Ala Ile Glu Glu Met Glu Arg Asp Gly 180

CTA GAA AGG GCC ATT GCT TTC ACA CAG TAT CCA CAG TAT AGC TGC TTC ACC ACC GGC AGC 600 Leu Glu Arg Ala Ile Ala the Thr Gln Tyr Pro Gln Tyr ser Cys Phe Thr Thr Gly Ser 200

AGT TTA AAT GCC ATT TAC AGA TAC TAT AAC GAG ATG GGA CGG AAG CCC ACC ATG AAG TGG 660 Ser Leu Asn Ala Ile Tyr Arg Tyr Tyr Asn Glu Met Gly Arg Lys Pro Thr Met Lys Trp 220

AGC ACA ATT GAC AGG TGG CCC ACG CAT CCC CTC CTC ATC CAG TGC TTT GCA GAC CAC ATT 720 Ser Thr Ile Asp Arg Trp Pro Thr His pro Leu Leu Ile Gln Cys Phe Ala Asp His Ile 240

CTG AAA GAA CTG GAC CAT TTT CCG CGG GAG AAG AGA AGC GAG GTG GTG ATT CTG TTT TCT 780 Leu Lys Glu Leu Asp His phe pro Arg Glu Lys Arg Ser Glu val val Ile Leu phe Ser 260

GCC CAC TCC CTG CCA ATG TCC GTT GTC AAC AGA GGA GAT CCC TAT CCC CAG GAA GTA GGT 840 Ala His Ser Leu Pro Met Ser val val Asn Arg Gly Asp Pro Tyr Pro Gln Glu val Gly 280

GCC ACT GTC CAC AAA GTC ATG GAA GAA CTA GGT TAT CCC AAC CCC TAC CGA CTG GTT TGG 900 Ala Thr val His Lys Val Met Glu Glu Leu Gly Tyr Pro Asn Pro Tyr Arg Leu Val Trp 300

CAG TCC AAG GTT GGC CCA GTA CCC TGG CTG GGT CCT CAA ACA GAT GAG GCC ATC AAA GGG 960 Gln ser Lys val Gly pro val pro Trp Leu Gly Pro Gln Thr Asp Glu Ala Ile Lys Gly 320

CTT TGT GAG AGA GGG AGG AAG AAT ATT CTC TTG GTT CCA ATA GCA TTT ACC AGT GAT CAC 1020 Leu Cys Glu Arg Gly Arg Lys Asn Ile Leu Leu val pro Ile Ala phe Thr Ser Asp His 340

ATC GAG ACC CTG TAT GAA CTG GAT ATT GAA TAC TCC CAA GTG TTA GCC AAG AAG TGT GAA 1080 Ile Glu Thr Leu Tyr Glu Leu Asp Ile Glu Tyr Ser Gln val Leu Ala Lys Lys Cys Glu 360

GCT GAA AAC ATC AGA AGA GCG GAG TCT CTT AAT GGA AAT CCA TTG TTC TCT AAG GCC TTG 1140 Ala Glu Asn Ile Arg Arg Ala Glu Ser Leu Asn Gly Asn Pro Leu Phe Ser Lys Ala Leu 380

GCT GAT CTG GTA TAC TCA CAC ATC CAG TCA AAC AAG CTG TGC TCT ACG CAG TTG ACT CTG 1200 Ala Asp Leu val Tyr Ser His Ile Gln Ser Asn Lys Leu Cys Ser Thr Gln Leu Thr Leu 400

AGC TGC CCG CTC TGT GTA AAT CCT GTC TGC AGG GAG ACT AAA TCC TTC TTC ACC AGC CAG 1260 Ser Cys Pro Leu Cys val Asn Pro val Cys Arg Glu Thr Lys ser Phe Phe Thr Ser Gln 420

CAG CTG TGA ccctgcctgaggacccotgggattcacagatgcgccagcctccagacacctccaatggoaatgoaag 1336 Gln Leu *** ccacatagcctggacacagcctgtggacaaggatagtgatttctttcttgccttatttatgttactttatttttgt 1415 ttcctgtgtagtccacgctggcctccaaatgggcctcctgttcgaatttcctgaatgctaat agcatcacagacacac 1494 aaaattgtgttctoggggaatagactctgaaattctactgcggttctatttcatacacacatacagtgaatactc 1573 acaaccatt ctgggatcaatttctcatgtggaatgtctactgtgaaattccaggagtgagttttaagtttcatctt 1652 atgagacacacacagattctocact tactgccccaacagcctcctaaatagtattcoagtccccactatgtgctac 1731 tagtggtgaatgagatgtctacaacctcatggatgcaggttaagtgaatatagttaatttatgaaatataatttgtaaa 1810 agaattgggctgagggcatagct tagtgattgtgtgctggcctagcattcatgaggctcctagtttgatcccctgaaat 1889 acatgtcgatattatgttacctattcttccctaagtccatgggtaccaggatactggtgagttggcctctattgccag 1968 tgaagtcatcagtcatcggtcattgtggtgtccgtgaaagagtctcactctcctcccctgaaactgaaatgagtgctca 2047 tt caaaagtgctctgagatt tccccaggcacacagcccaataaatatatggaaattc....... 2105 


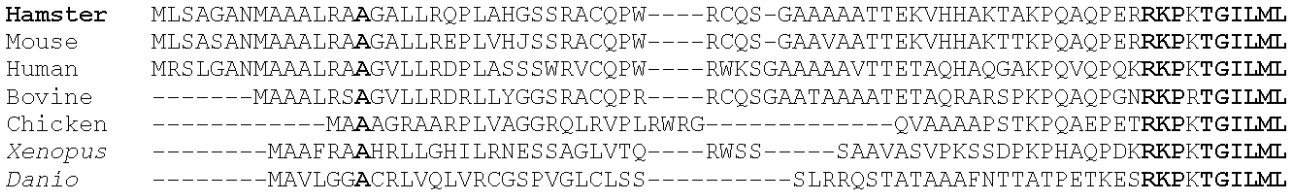

Hamster NMGGPETLGEVQDFLQRLFLDRDLMTLPIQNKLAPF IAKRRTPKIQEQYRRIGGGSP IKMWT SKQGEGMVKLLDELSP Mouse NMGGPETLGEVQDFLQRLFLDRDIMTLPIQNKLAPF IAKRRTPKIQEQYRRIGGGSPIKMWT SKQGEGMVKLLDELSP Human NMGGPETLGDVHDFLLRLFLDQDIMTLPIQNKLAPF IAKRRTPK IQEQYRRIGGGSP IK IWT SKQGEGMVKLLDELSP Bovine NMGGPETVEEVQDFLQRLFLDQDIMTLPVQDKLGPF IAKRRTPKIQEQYRRIGGGSP IKMWT SKQGEGMVKLLDELSP Chicken NMGGPERLDDVHDFLLRLFLDRDIMTLPAQNKLAPF IAKRRTPRIQEQYSRIGGGSP IKKWT AVQGEGMVKLLDSMSP Xenopus NMGGPETLDDVHGFLLRLFLDKDIMTLPAQSKLAPE IAKRRTPKIQEQYSKIGGGSP IKKWT EQQGEGMVKLLDELSP Danio NMGGPEKLEDVHDFLLRLFMDTDFMOLPVQNKLGPF IAKRRTPKIQEQYSKIGGGSP IKAWT TMQGEGMVKLLDEMCP

Hamster DTAPHKYYIGERYVHPLTEEAIEEMERDGLERAIAFTQYPQYSCETTGSSLNAIYRYYNEMGRKPTMKWST IDRWPTH Mouse Human Bovine ATAPHKYYIGFRYVHPLTE AIFEMERDGLERA IAFTQYPQYSCSTTGSSINAIYRYYNEVGOKPTMKWST IDRWPTH NTAPHKYYIGERYVHPLTEEAIEEMERDGLERAIAFTQYPQYSC TT GS SLNAIYRYYNQVGRKPTMKWST IDRWPTH HTAPHKYYIGERYVHPLTEEAIEEMERDGLERAVAFTQYPQYSCSTTGSSLNAIYRYYNEVGRKPTMKWST IDRWPTH OTAPHKYYIGERYVHPLTE EAIEEMEDDGIERAIAFTQYPQYSCSTTGS SLNAIYRYYNKKGKKPKMKWS I IDRWPTH ATAPHKYYIGERYVRPLTEAAIEEMERDGVERAIAFTQYPQYSCSTTGSSLNAIYRYYNAKGTQPKMKWSVIDRWPTH DTAPHKFYIGERYVHPLTEEAIEIMEKDGVERAVAFTQYPQYSCSTTGSSLNAIYRYYSNRADRPKMRWSVIDRWPTH

\begin{abstract}
Hamster PLLIQCFADHI LKELDHFPREKRSEVVILF SAHSLPMSVVNRGDPYPQEVGATVHKVMEELGYPNPYRLVWQSKVGPV Mouse Human Bovine Chicken Xenopus Danio PLLIQCFADHI LKELNHFPEEKRS EVVILF SAHSLPMSVVNRGDPYPQEVGATVHKVMEKLGYPNPYRLVWQSKVGPV HLLI $Q C F A D H I$ LKELDHFP LEKR SEVVILF SAHSLPMSVVNRGDPYPQEVSATVQKVMERLEYCNPYRLVWQSKVGPM PLLIQCFADHI LKELDHFPP EKRREVVILF SAHSLPMSVVNRGDPYPQEVGATVQRVMDKLGYSNPYRLVWQSKVGPM PLLI $Q C F A D H I Q K E L D L F P P D K R K D V V I L F S A H S L P M S V V N R G D P Y P Q E V G A T V Q R V M E K L N H S N P Y R L V W Q S K V G P M$ PLLIQCFADHIOKELDMFPADKRGEVVILF SAHSLPMSVVNRGDPYPOEVGATVOKVMERLGF SNPYRLVWOSKVGPM PLLIECFAEHVRNELDKFPVEKRDDVVILFSAHSLPLSVVNRGDPYPQEVGATVQRVMDRLGHCNPYRLVWQSKVGPM
\end{abstract}

\begin{abstract}
Hamster
Mouse

Human

Bovine

Chicken

Xenopus

Danio

$\begin{array}{ll}\text { Hamster } & \text { SHIQSNKLCSTQLTLSCPLCVNPVCRETKSFFTSQQL- } \\ \text { Mouse } & \text { SHIQSNKLCSTQLSLNCPLCVNPVCRKTKSFFTSQQL- } \\ \text { Human } & \text { SHIQSNELCSKQLTLSCPLCVNPVCRETKSFFTSQQL- } \\ \text { Bovine } & \text { SHLQSKERCSTQLTLSCPLCVNPTCRETKSFFTSQQL- } \\ \text { Chicken } & \text { SHIQSNEICSKQLTLCCPLCVNPVCRETKAFFTNQQL- } \\ \text { Xenopus } & \text { SHMKSSEICSKQLSLRCPMCVNPVCGEAKSFFTKQQQQ } \\ \text { Danio } & \text { SHLQSNESCSRQLTLRCPLCVNPTCAQTKAFFSSQKL- }\end{array}$
\end{abstract}

PWLGPQTDEAIKGLCERGRKN I LLVPIAFT SDHIETLYELDIEY SQVLAKKCEAENIRRAESLNGNPLF SKALADLVY PWLGPQTDEA IKGLCERGRKN I LLVPIAFT SDHIETL YELD IEY SQVLAQKCGAEN IRRAESLNGNPLFSKALADLVH PWLGPQTDES IKGLCORGKKN I LLVPIAFT SDHIETL YELDIEY SQVLAKECGVENIRRAESLNGNPLF SKALADLVH PWLGPQTDEA IKGLCKRGRKN I LLVPIAFT SDHIETL YELDIEY SQVLAS ECGLENIRRAESLNGNPLFSKALADLVH PWLVPQTDET IKGLC QRGKKNMLLVPIAFT SDHIETL YELD IEYAQVLANECGVENIRRAESLNGNPLFSKALADLVC AWLGPQTDE S IKGLC $O R G K K N$ I LLVPIAFT SDHIETL YELD IEYAOVLAKECGVENIRRSESLNGNPLF SKALADLVI AWLGPQTDEVIKGLC $Q R G K R N L L L V P I A F T$ SDHIETLHELD IEY SQVLGEEVGVENIRRAESLNGNPLF RALADLVQ

Figure 2 Amino-acid sequence comparison of hamster ferrochelatase to the mouse, human, bovine, chicken, Xenopus and Danio enzymes. The sequences are shown in single-letter code. Residues conserved among all species are in boldface. The conserved Cys residues at positions 195, 402, 405 and 410 in the hamster sequence are marked with an asterisk $\left({ }^{*}\right)$. Alignment was performed with the Multiple Sequence Alignment Program, Version $1 \cdot 8$ (clustalw.genome.jp/).

limited to the liver and, to a lesser extent, to HG (Fig. 3). The RNA length coincided with that predicted by sequencing of the cDNA. Since the mRNA level in HG and other tissues (data not shown) was too low to be detected by Northern blot, the tissue distribution of ferrochelatase mRNA was further assessed by RT-PCR assays in combination with Southern blot hybridization.
As shown in Fig. 4, the predicted 1320 bp cDNA product was detected in various tissues from males and females, including the liver, HG, adrenal glands and lung.

To explore the possibility that sex-steroid hormones were affecting ferrochelatase expression, semiquantitative RT-PCR assays were performed on tissue samples from intact and castrated male hamsters. Similar assays were

Figure 1 Nucleotide and predicted amino-acid sequences of hamster ferrochelatase cDNA. Position +1 is assigned to the first base of the putative initiator codon. Amino acids are numbered with position 1 assigned to the first methionine encoded. Numbering of the nucleotides (above) and amino acids (underneath) is shown on the right. The apparent polyadenylation signal (AATAAA) is underlined. 


\section{$\begin{array}{llll}1 & 2 & 3 & 4\end{array}$}

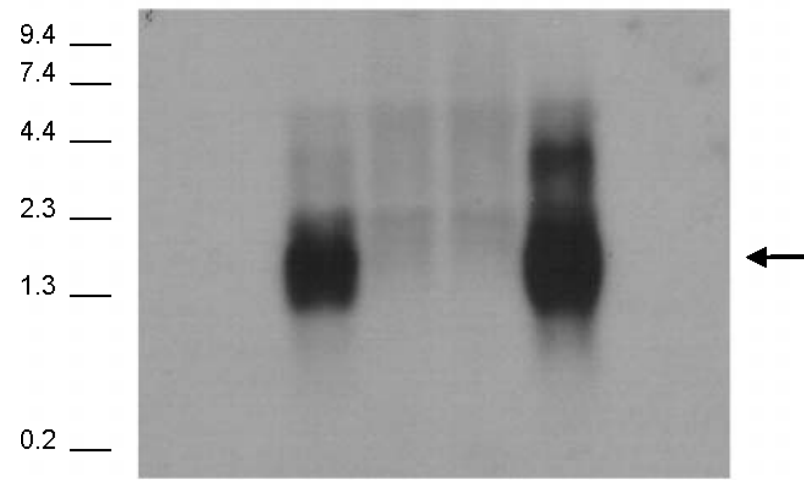

Figure 3 Northern blot of ferrochelatase mRNA. Total RNA (approximately $20 \mu \mathrm{g}$ ) from female liver (lane 1), female HG (lane 2), male HG (lane 3) and male liver (lane 4) was electrophoresed on a formaldehyde-agarose gel and transferred to a nylon membrane. Hybridization was carried out with a ${ }^{32}$ P-labelled ferrochelatase cDNA probe. Molecular size markers are 0.24-9.5 $\mathrm{kb}$ RNA ladder. Arrow indicates $2 \cdot 1 \mathrm{~kb}$ mRNA.

performed on tissues derived from female hamsters in the different phases of the oestrous cycle. The relative abundance of ferrochelatase mRNA was obtained by normalizing the $753 \mathrm{bp}$ band intensity with the band intensity of the constitutively expressed gene cyclophilin. As shown in Fig. 5, the results of densitometric analysis showed no significant variations in hepatic ferrochelatase mRNA during the oestrous cycle. The expression levels in liver of both intact and castrated males exhibited significant differences from those of females at dioestrus $(P<0 \cdot 001)$.
FECH

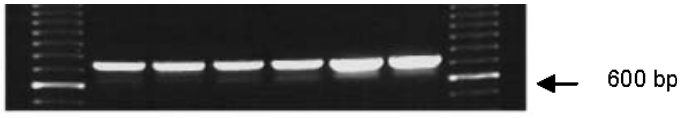

CY
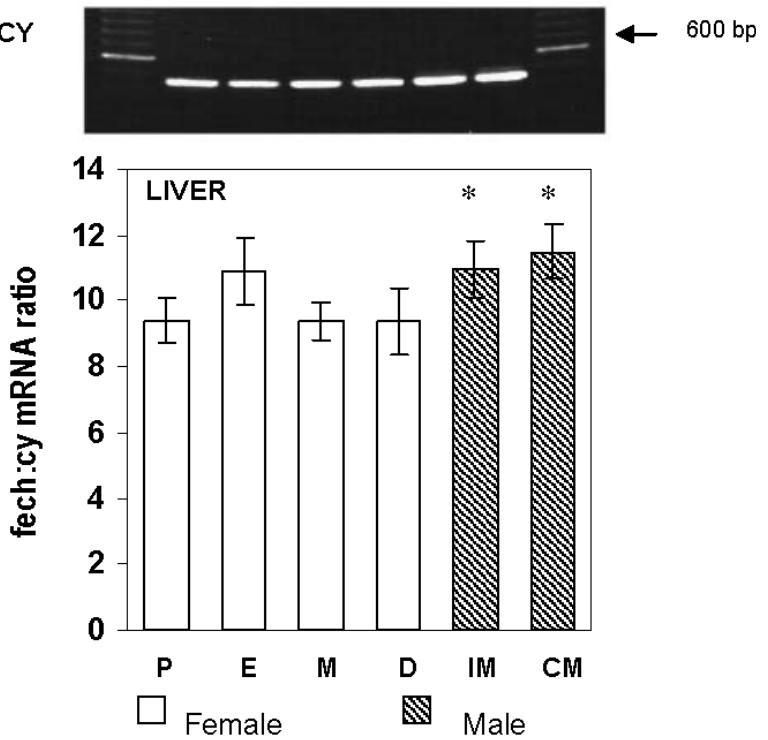

Figure 5 Expression levels of ferrochelatase mRNA in hamster liver. Complementary DNAs obtained from intact males (IM), castrated males (CM) and females at different phases of the oestrous cycle; proestrus $(\mathrm{P})$, oestrus $(\mathrm{E})$, metoestrus $(\mathrm{M})$ and dioestrus (D), were used to amplify specific transcripts for ferrochelatase $(\mathrm{FECH})$ and cyclophilin $(\mathrm{CY})$. Normalization of the relative optical densities of RT-PCR products of FECH (753 bp) and $C Y(450 \mathrm{bp})$ is shown in the lower panel. Ethidium bromide-stained gels represent one experiment, and bars represent the mean \pm s.D. $(n=7)$. Arrow indicates 100 bp DNA marker. ${ }^{*} P<0 \cdot 001$ vs dioestrus (D).

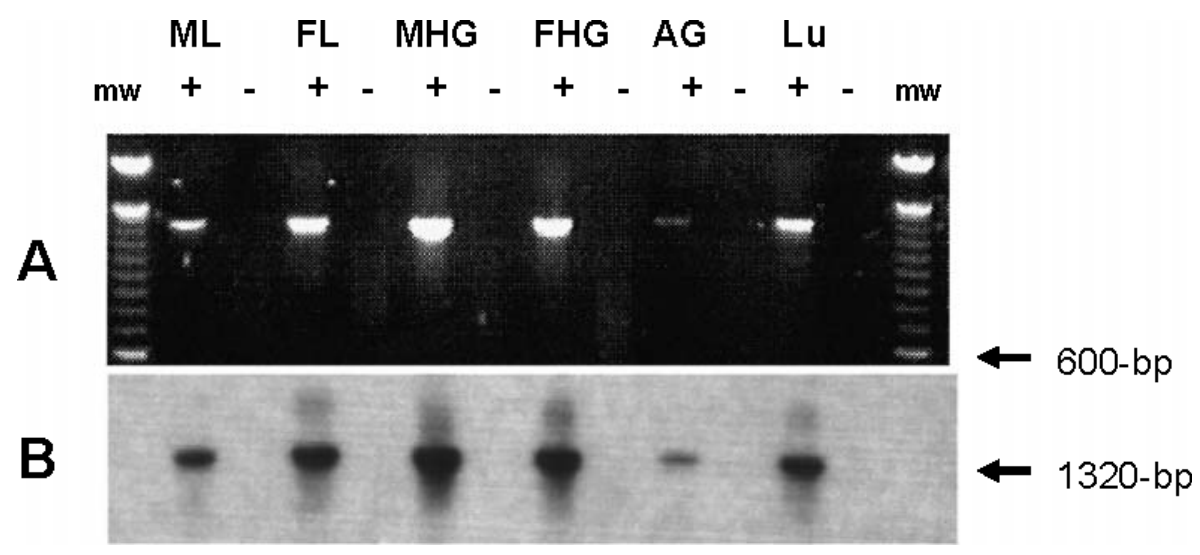

Figure 4 Expression of ferrochelatase mRNA in hamster tissues as revealed by RT-PCR followed by Southern blot hybridization. (A) Ethidium bromide-stained agarose gel of RT-PCR carried out with primers FPLUS-FMINUS. (B) Autoradiography of Southern blot with a 730 bp ${ }^{32}$ P-labelled ferrochelatase probe. RNA from male liver (ML), female liver ( $F L)$, male HG (MHG), female HG (FHG), adrenal gland (AG) and lung (Lu) was used to prepare cDNA, in presence (+) or absence $(-)$ of AMV reverse transcriptase. Lane mw, 100 bp DNA ladder as size standard. 

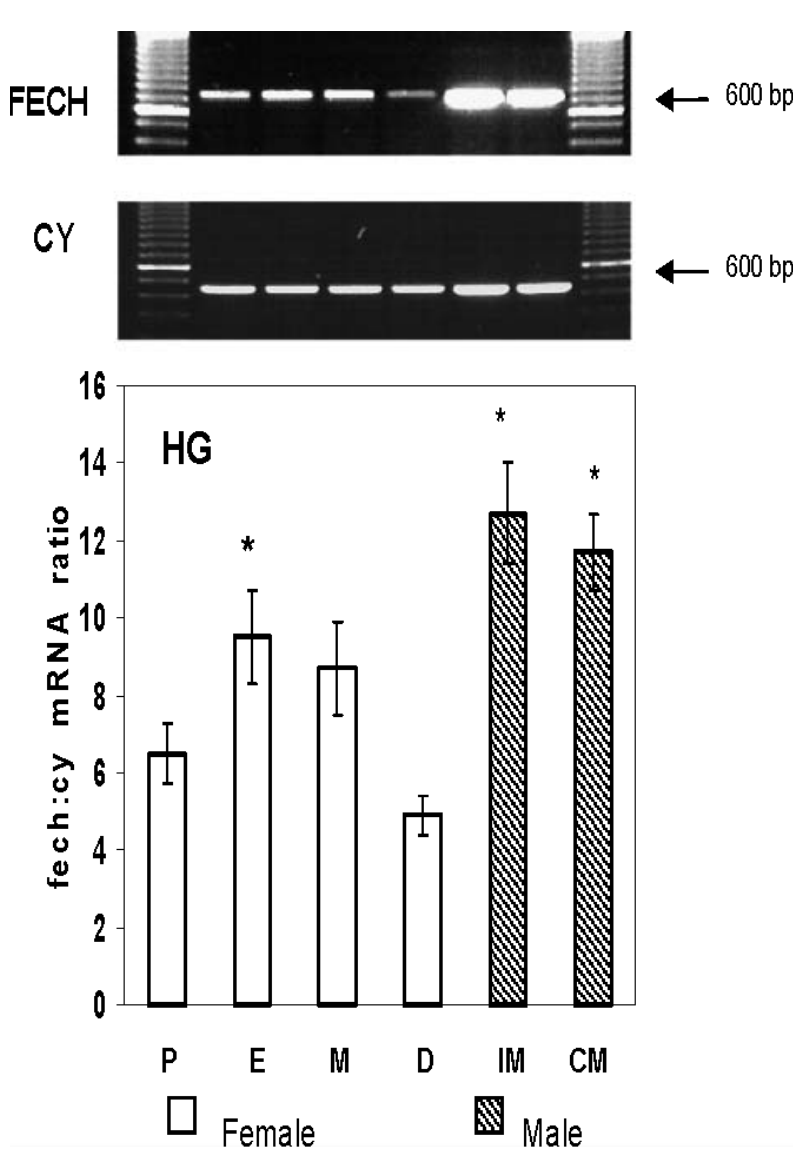

Figure 6 Expression levels of ferrochelatase mRNA in hamster Harderian gland (HG). Complementary DNAs obtained from intact males (IM), castrated males (CM) and females at different phases of the oestrous cycle; proestrus $(\mathrm{P})$, oestrus $(\mathrm{E})$, metoestrus $(\mathrm{M})$ and dioestrus (D) were used to amplify specific transcripts for ferrochelatase $(\mathrm{FECH})$ and cyclophilin $(\mathrm{CY})$. Normalization of the relative optical densities of RT-PCR products of FECH (753 bp) and $\mathrm{CY}$ (450 bp) is shown in the lower panel. Ethidium bromide-stained gels represent one experiment, and bars represent the mean \pm S.D. $(n=7)$. Arrow indicates 100 bp DNA marker. ${ }^{*} P<0 \cdot 001$ vs dioestrus (D).

On the other hand, the HG ferrochelatase mRNA showed marked variations during the oestrous cycle, with the highest levels at oestrus and lowest levels at dioestrus (Fig. 6). Consistently, the mRNA expression in male gland was higher than that found in female gland (Fig. 6). To assess the influence of sex steroid on the expression of ferrochelatase, groups of castrated hamsters were treated with different gonadal steroids. Figure 7 shows that the administration of progesterone or $17 \beta$-oestradiol to spayed females, or of testosterone to castrated males, does not modify significantly the amount of mRNA of liver. Figure 8 shows the ferrochelatase:cyclophilin ratio in the HGs from gonadectomized, treated animals. Here, the administration of progesterone or progesterone plus $17 \beta$-oestradiol to spayed females was shown to increase
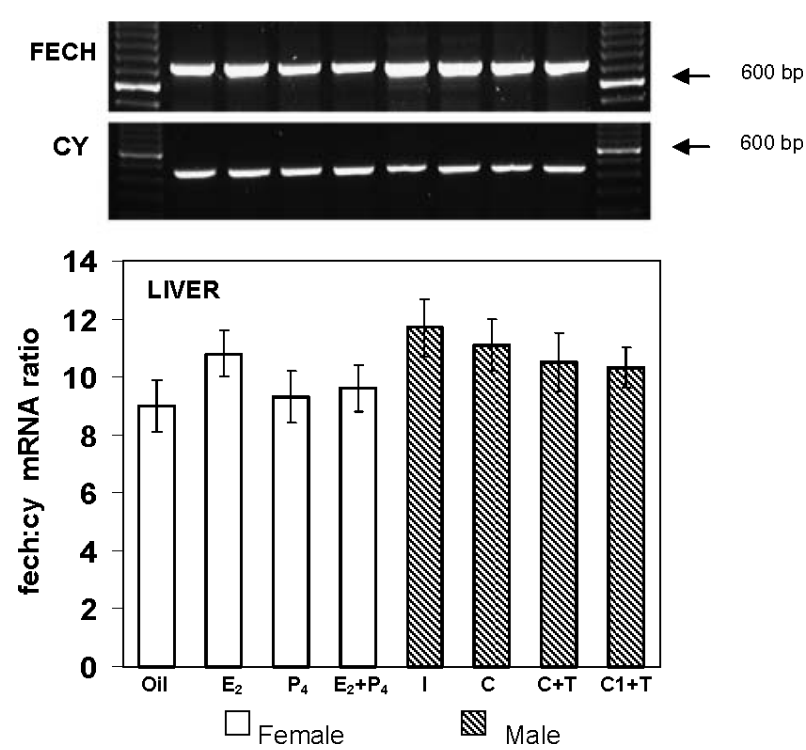

Figure 7 Effect of sex-steroid hormones on the ferrochelatase mRNA levels in liver of gonadectomized hamsters. Samples of liver CDNA from spayed females treated with oestradiol benzoate $\left(E_{2}\right)$, progesterone $\left(\mathrm{P}_{4}\right)$, oestradiol plus progesterone $\left(\mathrm{E}_{2}+\mathrm{P}_{4}\right)$ or vehicle alone (oil); intact males (I), castrated males (C), and males castrated for $7(\mathrm{C}+\mathrm{T})$ or 30 days $(\mathrm{C} 1+\mathrm{T})$ and treated with testosterone, were used to amplify specific transcripts of ferrochelatase $(\mathrm{FECH})$ and cyclophilin $(\mathrm{CY})$. Normalization of the relative optical densities of RT-PCR products for $\mathrm{FECH}$ (753 bp) and $\mathrm{CY}(450 \mathrm{bp})$ is shown in the lower panel. Ethidium bromide-stained gels represent one experiment, and bars represent the mean \pm S.D. $(n=6)$. Arrow indicates $100 \mathrm{bp}$ DNA marker.

significantly $(P<0 \cdot 05)$ the amount of mRNA for ferrochelatase. In HGs from short- or long-term castrated males, testosterone had no significant effect.

\section{Discussion}

Here we have isolated and sequenced a cDNA-encoding ferrochelatase from hamster mRNA by RT-PCR and RACE methods. The results from this study show the transcriptional activity of ferrochelatase in Syrian hamster HGs. Differences in the HG mRNA content of males and females were found, as were variations in the female oestrous cycle. The isolated cDNA comprises 2175 nucleotides, including $70 \mathrm{bp}$ of the $5^{\prime}-\mathrm{UTR}, 1266 \mathrm{bp}$ of the open reading frame, and a long $3^{\prime}$-UTR of $839 \mathrm{bp}$ followed by a poly(A) tail. Interestingly, it encodes a 422-amino-acid precursor molecule of ferrochelatase with a signal peptide of 48 amino acids followed by a mature protein of 374 amino acids. Some amino-acid residues are conserved among the vertebrate ferrochelatases and are present within the hamster sequence. These residues include a histidine at position $262\left(\mathrm{His}_{262}\right)$, considered to be involved in substrate iron binding (Franco et al. 1995); 

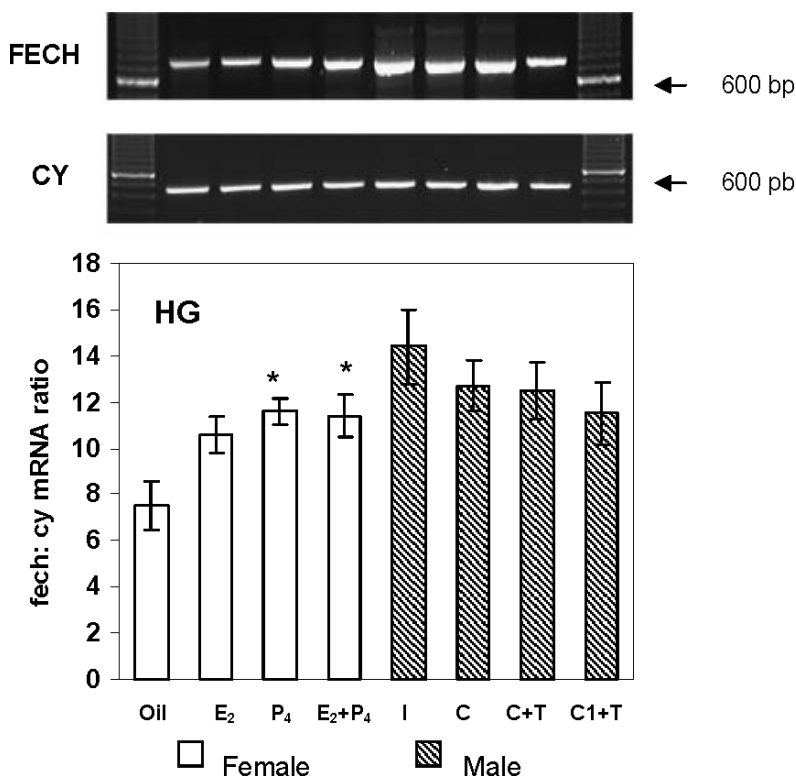

Figure 8 Effect of sex-steroid hormones on the ferrochelatase mRNA levels in Harderian gland (HG) of gonadectomized hamsters. Samples of HG cDNA from spayed females treated with oestradiol benzoate $\left(E_{2}\right)$, progesterone $\left(P_{4}\right)$, oestradiol plus progesterone $\left(\mathrm{E}_{2}+\mathrm{P}_{4}\right)$ or vehicle alone (oil); intact males (I), castrated males $(\mathrm{C})$, and males castrated for $7(\mathrm{C}+\mathrm{T})$ or 30 days $(\mathrm{C} 1+\mathrm{T})$ and treated with testosterone, were used to amplify specific transcripts of ferrochelatase $(\mathrm{FECH})$ and cyclophilin $(\mathrm{CY})$. Normalization of the relative optical densities of RT-PCR products for FECH (753 bp) and CY (450 bp) is shown in the lower panel. Ethidium bromide-stained gels represent one experiment, and bars represent the mean \pm S.D. $(n=6)$. Arrow indicates $100 \mathrm{bp}$ DNA marker. ${ }^{*} P<0 \cdot 05$ vs control group (oil).

a glutamic acid residue $\left(\mathrm{Glu}_{288}\right)$, considered to be involved in catalysis (Ferreira et al. 1999); and the four cysteine residues $\left(\mathrm{Cys}_{195}, \mathrm{Cys}_{402}, \mathrm{Cys}_{405}\right.$ and Cys 410 ), considered to be the $[2 \mathrm{Fe}-2 \mathrm{~S}]$ cluster ligands (Sellers et al. 1998, Dailey et al. 2000). While the key function of His 262 and Glu188 are recognized in a number of studies, the results from site-directed mutagenesis experiments have brought into question the putative role of His262 in substrate iron binding (Dailey et al. 2000).

At present, relatively little is known about the regulation of porphyrin synthesis and the role of ferrochelatase in the physiology of the rodent HG. Unlike what occurs in other porphyrinogenic tissues, such as the liver and the adrenal gland, it is not known whether HG ferrochelatase uses iron from intracellular sources or whether it depends on an extracellular source of iron (transferrin). Recent studies have demonstrated that frataxin, a nuclearencoded protein, plays an important role in both haem and iron-sulphur cluster biosynthesis. Frataxin can act as a mitochondrial iron donor to transport $\mathrm{Fe}(\mathrm{II})$ not only to ferrochelatase but also to ISU proteins (He et al. 2004, Yoon \& Cowan 2005). It is very likely that frataxin is also present in hamsters, since this mitochondrial protein has been identified from invertebrates up to mammals (Ventura et al. 2005). Nevertheless, the role of frataxin or its possible expression in $\mathrm{HG}$ has not been examined and remains to be investigated. There is evidence that iron is present at large concentrations in the male HG (Hoffman \& Jones 1981); and it is known that ferrochelatase activity is under the control of intracellular iron, which possibly is correlated with formation of the $[2 \mathrm{Fe}-2 \mathrm{~S}]$ cluster at the C-terminal region (Taketani et al. 2000).

In nonerythroid cells, the rate-limiting step of haem production is mediated by ALA-S1, an enzyme whose synthesis is under feedback inhibition by haem. There is also evidence that the activity of this enzyme is regulated by testosterone and 5a-DHT (Veltman \& Maines 1985). Unlike ALA-S1, which is expressed ubiquitously, ALA-S2 is expressed only in differentiating erythroid precursor cells and appears not to be inhibited by haem (Sassa \& Nagai 1996).

Data from previous reports have suggested an androgenic regulation of this pathway in HG. Thus, while the female HG expresses higher amounts of ALA-S1 mRNA than the male HG, the administration of testosterone or $5 \alpha$-DHT to females led to a reduction in the levels of ALA-S1 mRNA. Moreover, the castration of males causes a marked elevation in ALA-S1 mRNA levels (MenéndezPeláez et al. 1991, Rodríguez et al. 1993, Domínguez et al. 1994). Under these endocrine conditions, the concentrations of porphyrins in the HG show a strong correlation with the levels of ALA-S1 mRNA, indicating that factors other than haem may be modulating porphyrin synthesis. In this regard, the role of haem in HG physiology appears to be even less clear, particularly because the cellular content of haem is nearly undetectable and because HG ferrochelatase activity is minimal (Thompson et al. 1984, Nagai et al. 1997). Although the incorporation of ferrous iron into protoporphyrin IX to form haem has not been clearly demonstrated in Harderian tissue, the specific synthesis of considerable amounts of androgen-induced haemoproteins, whose production shows gender-associated differences (Vilchis et al. 1996), along with the relative content of glandular cytochrome P450 scc (Vilchis et al. 2002), is indirect evidence of local ferrochelatase activity.

As an initial step to define more clearly the role of this enzyme in the HG, we first assessed its transcriptional activity by analysing mRNA levels and determined whether ferrochelatase is expressed differentially in males and females. Northern blot analyses showed positive hybridization in samples of liver RNA with little or almost undetectable hybridization signal in HG preparations, suggesting a low transcriptional activity in this tissue. Similarly, low expression levels have also been detected by Northern blot analysis of murine ferrochelatase (Brenner \& Frasier 1991). As shown in Fig. 5, the level of ferrochelatase mRNA was slightly higher in the liver of males than the livers of females. Apparently, the amount of hepatic mRNA is not influenced by the sex-steroid 
hormones, since no significant differences were found during the distinct phases of the oestrous cycle, nor after the administration of sex-steroid hormones to spayed females (Fig. 7). In contrast to what occurs in liver, the content of ferrochelatase mRNA of the HG changed during the oestrous cycle. The intraglandular messenger levels were significantly higher at oestrus than at dioestrus. A similar cyclic pattern has been reported for the porphyrin concentrations in the female HG (Payne et al. 1979). The changes in the relative expression of ferrochelatase are probably modulated by circulating ovarian steroids, since this organ has been shown to be largely responsive to oestrogenic stimuli (Payne 1994), and the presence of specific receptors for oestrogens is well documented (Vilchis \& Pérez-Palacios 1989, Vilchis et al. 1992). In HGs of cyclic hamsters, the maximal expression of ferrochelatase mRNA was observed at oestrus, a phase where the concentrations of oestradiol and progesterone have already declined to basal levels. This response may reflect a delayed effect induced by the high concentrations of oestradiol and/or progesterone that are normally present at proestrus (Smith et al. 1975, Vomachka \& Greenwald 1979). On the other hand, in ovariectomized animals (Fig. 8), the levels of mRNA for the enzyme also increased significantly after treatment with progesterone or progesterone plus oestradiol, thus indicating involvement of ovarian steroids in the control of the Harderian ferrochelatase. However, these results could have been influenced by either the dose of steroids employed or the duration of treatment.

Both male gland histology and activity are known to be under hormonal control (Hoffman 1971, Payne 1979). Notably, male sex steroids sustain repressive effects on ALA-S1 activity and porphyrin levels (Domínguez et al. 1994) but do not change the abundance of type II cells (McMasters \& Hoffman 1984) or the output of a haemcontaining protein, which was considered to be involved in regulation of porphyrin synthesis (Vilchis et al. 1996). Here we found that the male HG contains less ferrochelatase mRNA than the liver, and the level of mRNA expression was not modified by castration or by the administration of testosterone to castrated males. These findings are consistent with the view that androgens have little influence on the rate of haem production. The low expression of ferrochelatase gene in the HG may explain its low haem content, although it is unlikely that haem levels inhibit HG porphyrinogenesis. However, the role of ferrochelatase in regulating porphyrin synthesis cannot be completely ruled out since haem concentrations as low as $10^{-7} \mathrm{M}$ can suppress the formation of ALA-S (May et al. 1990, Spike et al. 1992). The data presented herein suggest that the Harderian ferrochelatase may function as a housekeeping enzyme to maintain the physiological pool of haem required for the cellular processing of cytochromes and other biologically active haemoproteins. In this organ, the control of porphyrin synthesis appears to be accomplished by mechanisms other than ferrochelatase-mediated haem production.

\section{Acknowledgements}

This work was partially supported by CONACYT grant no. 44975 (México). L R received a postgraduate studentship from CONACYT (Reg. 167215). We thank Mat. Margarita Chávez (Facultad de Ciencias, UNAM) for her invaluable assistance in statistical analysis. The authors declare that there is no conflict of interest that would prejudice the impartiality of this scientific work.

\section{References}

Brenner DA \& Frasier F 1991 Cloning of murine ferrochelatase. PNAS 88 849-853.

Buzzell GR, Hoffman RA, Vaughan MK \& Reiter RJ 1992 Hypophysectomy prevents the castration-induced increase in porphyrin concentrations in the Harderian glands of the male golden hamster: a possible role for prolactin. Journal of Endocrinology $13329-35$.

Christensen F \& Dam H 1953 A sexual dimorphism of the Harderian glands in hamsters. Acta Physiologica Scandinavica 27 333-336.

Coto-Montes A, Boga JA, Tomas-Zapico C, Rodríguez-Colunga MJ, Martínez Fraga J, Tolivia CD, Menéndez G, Hardeland R \& Tolivia D 2001 Porphyric enzymes in hamster Harderian gland, a model of damage by porphyrins and their precursors. A chronobiological study on the role of sex differences. Chemico-Biological Interactions 134 135-139.

Dailey HA, Dailey TA, Wu CK, Medlock AE, Wang KF, Rose JP \& Wang BC 2000 Ferrochelatase at the millennium: structures, mechanisms, and $[2 \mathrm{Fe}-2 \mathrm{~S}]$ clusters. Cellular and Molecular Life Sciences 57 1909-1926.

Domínguez P, Antolín I, Boga JA, Uría H \& Menéndez Peláez A 1994 Androgen regulation of gene expression in the Syrian hamster Harderian gland. Molecular and Cellular Endocrinology 106 81-89.

Drew PD \& Ades IZ 1986 Regulation of production of embryonic chick liver delta-aminolevulinate synthase, effects of testosterone and of hemin on the mRNA of the enzyme. Biochemical and Biophysical Research Communications 140 81-87.

Ferreira G 1999 Molecules in focus: ferrochelatase. International Journal of Biochemistry and Cell Biology 31 995-1000.

Franco R, Moura JG \& Moura I 1995 Characterization of the iron-binding site in mammalian ferrochelatase by kinetic and Mössbauer methods. Journal of Biological Chemistry 270 26352-26357.

Gibson SL, Anderson LT, Havens JL \& Hilf R 1999 Effect of estrogenic perturbations on $\delta$-aminolevulinic acid-induced porphobilinogen deaminase and protoporphyrin IX levels in rat harderian glands, liver and R3230AC tumors. Biochemical Pharmacology 58 1821-1829.

He Y, Alam SL, Proteasa SV, Zhang Y, Lesuisse E, Dancis A \& Stemmler TL 2004 Yeast frataxin solution structure, iron binding, and ferrochelatase interaction. Biochemistry 43 16254-16262.

Hoffman RA 1971 Influence of some endocrine glands, hormones and blinding on the histology and porphyrins of the Harderian glands of golden hamsters. American Journal of Anatomy 132 463-478.

Hoffman RA \& Jones JW 1981 Concentrations of metals in the Harderian glands of male and female hamsters. Comparative Biochemistry and Physiology 69A 153-156.

Hoffman RA, Johnson LB \& Reiter RJ 1985 Harderian glands of golden hamsters: temporal and sexual differences in immunoreactive melatonin. Journal of Pineal Research 2 161-168. 
Hoffman RA, Habeeb P \& Buzzell GR 1990 Further studies on the regulation of the Harderian glands of golden hamsters by the thyroid gland. Journal of Comparative Physiology B 160 269-275.

Kozak M 1987 An analysis of $5^{\prime}$-noncoding sequences from 699 vertebrate messenger RNAs. Nucleic Acids Research 15 8125-8131.

May BK, Bhasker CR, Bawden MJ \& Cox TC 1990 Molecular regulation of 5 -aminolevulinate synthase: diseases related to heme biosynthesis. Molecular Biology and Medicine 7 405-421.

McMasters KM \& Hoffman RA 1984 Harderian gland: regulation of sexual 'type' by gonads and pineal gland. Biology of Reproduction 31 579-585

Menéndez-Peláez A, Rodriguez C \& Dominguez P 1991 5-Aminolevulinate synthase mRNA levels in the Harderian gland of Syrian hamsters: correlation with porphyrin concentrations and regulation by androgens and melatonin. Molecular and Cellular Endocrinology 80 177-182.

Moore MR, Thompson GG, Payne AP \& McGadey J 1977 Cyclical oscillations in the activity of $\delta$-aminolaevulinate synthase and porphyrin synthesis in the Harderian gland during oestrus cycle of the golden hamster (Mesocricetus auratus). Biochemical Society Transactions 5 1475-1478.

Nagai M, Nagai T, Yamamoto M, Goto K, Bishop TR, Hayashi N, Kondo H, Seyama Y Kano K, Fujita H et al. 1997 Novel regulation of delta-aminolevulinate synthase in the rat harderian gland. Biochemical Pharmacology 53 643-650.

Nakahashi Y, Taketani S, Okuda M, Inoue K \& Tokunaga R 1990 Molecular cloning and sequence analysis of cDNA encoding human ferrochelatase. Biochemical and Biophysical Research Communications 173 748-755.

Payne AP 1994 The harderian gland: a tercentennial review. Journal of Anatomy 185 1-49.

Payne AP, McGadey J, Moore MR \& Thompson G 1977 Androgenic control of the Harderian gland in the male golden hamster. Journal of Endocrinology 75 73-82.

Payne AP, McGadey J, Moore MR \& Thompson GG 1979 Changes in the Harderian gland activity in the female golden hamster during the oestrus cycle, pregnancy and lactation. Biochemical Journal 178 597-604.

Ponka P 1999 Cell biology of heme. American Journal of Medical Sciences 318 241-256.

Rodríguez C, Menéndez-Peláez A, Vaughan MK \& Reither RJ 1993 Gender-associated differences in the development of 5 -aminolevulinate synthase gene expression in the Harderian gland of Syrian hamsters. Molecular and Cellular Endocrinology 93 167-173.

Sassa S \& Nagai T 1996 The role of heme in gene expression. International Journal of Hematology 63 167-178.

Sellers VM, Wang KF, Johnson MK \& Dailey HA 1998 Evidence that the fourth ligand to the $[2 \mathrm{Fe}-2 \mathrm{~S}]$ cluster in animal ferrochelatase is a cysteine. Journal of Biological Chemistry 273 22311-22316.

Shibuya H, Nonneman D, Tamassia M, Allphin OL \& Johnson GS 1995 The coding sequence of the bovine ferrochelatase gene. Biochemica et Biophysica Acta 1231 117-120.

Siegel S \& Castellan NJ 1988 The Kruskal-Wallis one-way analysis of variance by ranks. In Nonparametric Statistics for the Behavioural Sciences, 2nd edn, pp 206-213. Ed JD Pinker. New York, NY, USA: McGraw-Hill.

Smith MS, Freeman ME \& Neill JD 1975 The control of progesterone secretion during the estrous cycle and early pseudopregnancy in the rat: prolactin, gonadotropin and steroid levels associated with rescue of the corpus luteum of pseudopregnancy. Endocrinology 96 219-226.

Spike RC, Johnston HS, McGadey J, Moore MR, Thompson GG \& Payne AP 1985 Quantitative studies on the effects of hormones on structure and porphyrin biosynthesis in the Harderian gland of the female golden hamster. I. The effects of ovariectomy and androgen administration. Journal of Anatomy 142 59-72.

Spike RC, Johnston HS, McGadey J, Moore MR, Thompson GG \& Payne AP 1986 Quantitative studies on the effects of hormones on structure and porphyrin biosynthesis in the Harderian gland of the female golden hamster. II. The time course of changes after ovariectomy. Journal of Anatomy 145 67-77.

Spike RC, Payne AP \& Moore MR 1992 Porphyrins and their possible significance in Harderian glands. In Harderian Glands: Porphyrin Metabolism, Behavioural and Endocrine Effects, pp 165-193. Eds SM Webb, RA Hoffman, ML Puig-Domingo \& RJ Reiter. Berlin, Germany: Springer-Verlag.

Taketani S, Nakahashi Y, Osumi T \& Tokunaga R 1990 Molecular cloning, sequencing, and expression of mouse ferrochelatase. Journal of Biological Chemistry 265 19377-19380.

Taketani S, Adachi Y \& Nakahashi Y 2000 Regulation of the expression of human ferrochelatase by intracellular iron levels. European Journal of Biochemistry 267 4685-4692.

Thompson GG, Hordovatzi X, Moore MR, McGadey J \& Payne AP 1984 Sex differences in haem biosynthesis and porphyrin content in the Harderian gland of the golden hamster. International Journal of Biochemistry 16 849-852.

Tomio JM \& Grinstein M 1968 Porphyrin biosynthesis. V. Biosynthesis of protoporphyrin IX in the Harderian glands. European Journal of Biochemistry 6 80-83.

Veltman JC \& Maines MD 1985 Sex difference in adrenal heme and cytochrome p-450 metabolism: evidence for the repressive regulatory role of testosterone. Journal of Pharmacology and Experimental Therapeutics 235 71-75.

Ventura N, Rea S, Henderson ST, Condo I, Johnson TE \& Testi R 2005 Reduced expression of frataxin extends the lifespan of Caenorhabditis elegans. Aging Cell 2 109-112.

Vilchis F \& Pérez-Palacios G 1989 Steroid hormone receptors and the sexual phenotype of the Harderian gland in hamsters. Journal of Endocrinology 121 149-159.

Vilchis F, Chávez B, Cerbón MA \& Pérez-Palacios G 1992 The Harderian gland as a target for steroid hormone action: role and characteristics of intracellular receptors. In Harderian Glands: Porphyrin Metabolism, Behavioural and Endocrine Effects, pp 297-316. Eds SM Webb, RA Hoffman, ML Puig-Domingo \& RJ Reiter. Berlin, Germany: Springer-Verlag.

Vilchis F, Damsky R, Heuze Y, Enríquez J \& Chávez B 1996 Identification and androgen regulation of a $156-\mathrm{kDa}$ hemeprotein in the Harderian gland of the Syrian hamster. General and Comparative Endocrinology 101 297-303.

Vilchis F, Chávez B, Larrea F, Timossi C \& Montiel F 2002 The cDNA cloning and tissue expression of the cytochrome P450 scc from Syrian hamster (Mesocricetus auratus). General and Comparative Endocrinology 126 279-286.

Vomachka AJ \& Greenwald GS 1979 The development of gonadotropin and steroid hormone patterns in male and female hamsters from birth to puberty. Endocrinology 105 960-966.

Wetterberg L, Geller E \& Yuwiler A 1970 Harderian gland: An extraretinal photoreceptor influencing the pineal gland in neonatal rats? Science $167884-885$

Yoon T \& Cowan JA 2004 Frataxin-mediated iron delivery to ferrochelatase in the final step of heme biosynthesis. Journal of Biological Chemistry 279 25943-25946.

Received in final form 30 December 2005

Accepted 18 January 2006 